\title{
Chapter \#\#
}

Genome-reduced Corynebacterium glutamicum fit for biotechnological applications

Volker F. Wendisch

Genetics of Prokaryotes, Faculty of Biology and Center for Biotechnology (CeBiTec), Bielefeld University, Bielefeld, Germany

E-mail: volker.wendisch@uni-bielefeld.de

ORCID: 0000-0003-3473-0012

Google Scholar Profile: XBj3q30AAAAJ

Researcher ID: M-5940-2016

Scopus Author ID: 6701420809 
ABSTRACT: Genome minimization ultimately leads to the smallest genome sustaining life of a given cell, however, growth of this cell may be very slow and may require multiple supplements e.g. to overcome amino acid auxotrophies. By contrast, genome reduction of industrially relevant bacteria such as Corynebacterium glutamicum does not aim at generating minimal cells. Rather chassis cells are developed that are as fit as the wild type with respect to a target function: for example growth of $C$. glutamicum in glucose minimal medium. Thus, a balance between reducing the burden of expressed genes while maintaining fast growth with glucose without the requirement for supplements such as amino acids is required. Here, the application of this concept to $C$. glutamicum is discussed. Moreover, an outlook on how the advent of genome editing by CRISPR-Cas9 or CRISPR-Cpf1 impacts genome reduction and how highly parallel genome editing must be met by highly parallel strain characterization is presented. Finally, metabolic engineering approaches for the overproduction of amino acids, organic acids, terpenoids and diamines making use of genome-reduced $C$. glutamicum strains are detailed.

Keywords: Corynebacterium glutamicum; genome reduction; amino acid production; metabolic engineering; fine chemicals; two-step homologous recombination, CRISPR/Cas9 


\section{\#\#.1 Corynebacterium glutamicum: one of the pillars of biotechnology}

\#\#.1.1 Role of C. glutamicum in the bioeconomy

It is believed that bioeconomy will play an important role in the world's future. White biotechnology, also known as industrial biotechnology, makes use of biotechnology for the sustainable processing and production of chemicals, materials and fuel [1]. Corynebacterium glutamicum is a central pillar of white biotechnology. C. glutamicum has a history of more than fifty years of safe production of food and feed amino acids, an industrial process which operates at the million-ton scale per annum [2] and shows a compound annual growth rate of $5.6 \%$ over $2017-2022$ reaching US\$25.6 billion by 2022 [3].

Strain development for $C$. glutamicum has embraced and driven technological development in the classical [4-5], genetic engineering [6-7], systems biology [8], synthetic biology [2,9], and systems metabolic engineering eras [2, 10-11]. Currently, this is obvious by the application and further development of CRISPR interference [12], CRISPR-Cas9 [13] and CRISPR-Cpf1 [14] genome editing and CRISPR multiplexing [15], biosensor-driven strain selection [16-22] and flux control [23-24], new process concepts such as co-production [25] and synthetic consortia [26] that have been applied to C. glutamicum.

\section{\#\#.1.2 C. glutamicum as host for a multitude of production processes}

C. glutamicum has been engineered for the production of a broad spectrum of value-added compounds including specialty amino acids [27-28] such as N-alkylated amino acids [29-31] and omega-amino acids [32-35], diamines such as putrescine and cadaverine [36-37], organic acids such as pyruvate [38], succinate [39-42], glutarate [43] and itaconate [44], alcohols such as isobutanol [45-46] and n-propanol [47], aromatic compounds such as PHBA [48-50], 7chloro-L-tryptophan [51], phenylpropanoids [52] and anthocyanine [53], vitamins such as 
pantothenate [54] and riboflavin [55], terpenoids such as patchoulol [56] and astaxanthin [57], polymers such polyhydroxyalkanoates [58], hyaluronic acids [59], chondroitin [60] and proteins [61-62]. To facilitate biorefinery applications a flexible carbon feedstock concept has been realized for production processes from various second generation feedstocks without competing uses in human and animal nutrition [63-64].

\section{\#\#.1.3 C. glutamicum genome and genome-scale tools}

C. glutamicum possesses a single circular chromosome with 3.3 Mb [65-66] and more than 3,000 protein encoding sequences (CDS). Genome-scale methods have been developed early [67-68]. Based on the complete genome sequence [65], genome-scale metabolic models were reconstructed. The first genome-scale metabolic models followed the approach for the $E$. coli genome-scale metabolic model [69] and comprised 446 and 502 reactions, respectively, involving 441 and 423 metabolites, respectively [70-71]. The genome-scale model iEZ475 added balances for protons and water (https://www.13cflux.net/models/Corynebacterium_glutamicum/index.jsp) and contains 475 metabolic reactions involving 408 metabolites (340 intra- and 68 extracellular) that could be grouped to central carbon metabolism (about 42 reactions), amino acid synthesis (about 110 reactions) as well as to oxidative phosphorylation, membrane lipid metabolism, nucleotide salvage pathway, cofactor biosynthesis, biomass formation, alternate carbon $\begin{array}{lllll}\text { metabolism, and } & \text { about } & \text { transport } & \text { reactions }\end{array}$ (https://www.13cflux.net/models/Corynebacterium glutamicum/index.jsp). Biosynthesis reactions leading to protein, DNA, RNA and cell-wall components were accounted for based on their weight fraction of the biomass. The most advanced model (iCW773) has recently been described and reconstructs 773 genes, 950 metabolites, and 1207 reactions, of which 252 are 
transport reactions [72]. Although all these models are named genome-scale, only about $26 \%$ of all ORFs are covered by the most advanced model. These stoichiometric models were complemented by a regulatory model involving 97 transcriptional regulator proteins and 1,432 regulatory interactions which later was extended to include other corynebacterial species and E. coli [73].

Transcriptomics was developed for C. glutamicum, first based on DNA microarrays [67], later by RNAseq [74]. A landscape RNAseq study helped to refine genome annotation with a reannotation of 200 gene starts and the finding that among the 2,000 transcriptional start sites identified, about 33\% belonged to leaderless transcripts [74]. Differential RNAseq is nowadays used to compare global gene expression patterns [75-78]. Proteomics for cytoplasmic proteins, membrane fraction proteins, cell wall-associated proteins, and secreted proteins are now available [79-83]. This, for example, led to the discovery of pupylation as posttranslational modification that is relevant for iron release from the iron storage protein ferritin independent of degradation [84-85]. Metabolomics has been developed for $C$. glutamicum [86-87] and, for example, helped to identify a new pathway involving $\gamma$-glutamyl transpeptidase and $\gamma$-glutamyl dipeptides ( $\gamma$-Glu-Glu, $\gamma$-Glu-Gln, $\gamma$-Glu-Val, $\gamma$-Glu-Leu, $\nu$-GluMet) were detected by HPLC-MS in concentrations from 0.15 to $0.4 \mathrm{mg} / \mathrm{g} \mathrm{CDW}$ [88].

\section{\#\#.2 Prophage cured strains}

\#\#.2.1 MB001 derived from wild type ATCC 13032

The $C$. glutamicum genome contains three prophage DNA islands (CGP1, CGP2, and CGP3). CGP1 comprises genes cg1507 to cg1524 (13.5 kbp), CGP2 genes cg1746 to cg1752 (3.9 kbp), and CGP3 is the largest prophage region with $187.3 \mathrm{kbp}$ (comprising genes cg1890 to $\operatorname{cg} 2071$ $[65,89]$. The activity of bacteriophages and phage-related mobile elements is a major source 
for genome rearrangements and genetic instability of their bacterial hosts. Genome-wide expression analysis often revealed differential expression of phage genes [90-91]. Moreover, the large prophage CGP3 has recently been shown to be excised under SOS-response-inducing conditions [89]. Single-cell analyses with transcriptional fusions of promoters of phage genes (Pint2 and Plysin) to fluorescent protein reporter genes revealed that 0.01 to $0.08 \%$ of the cells grown in standard minimal medium induced CGP3 spontaneously, which reduced their viability. Apparently, spontaneously occurring DNA damage induced the SOS response and as consequence prophage induction [92]. This process required actively proliferating cells, whereas sporadic SOS induction was still observed in resting cells [93]. The prophage CGP3encoded nucleoid-associated protein CgpS binds AT-rich DNA as prevails in the entire CGP3 prophage region, but is scarce throughout the rest of the genome. In its absence a significantly increased induction frequency of the CGP3 prophage resulted, whereas a strain lacking the CGP3 prophage displayed stable growth [94]. Based on the properties of the prophages and the resulting genetic instability, the first target for genome reduction was the deletion of these prophage DNA islands [95].

Deletion of the three prophage DNA islands reduced the genome size of $C$. glutamicum ATCC 13032 by $6 \%$ and resulted in strain MB001. Its growth properties were unchanged under standard and stress conditions. Under SOS-response-inducing conditions that trigger CGP3 induction in the $C$. glutamicum wild type, strain MB001 fared better than the wild type showing improved growth and fitness. In addition, strain MB001 exhibited increased transformation efficiency. This was attributed to the loss of the restriction-modification system (cg1996-cg1998) located within CGP3. Furthermore, plasmid copy number appeared to be increased since production of a heterologous model protein (enhanced yellow 
fluorescent protein, eYFP) was $30 \%$ higher than in the wild type. Similarly, deletion of the genes for restriction-modification system (cg1996-cg1998) improved eYFP production [95]. These results characterized MB001 as an intermediate strain to be improved by further genome reduction (s. below), e.g. by targeting mobile IS elements, and as a suitable strain for metabolic engineering (stable, growing as fast as wild type on glucose minimal medium, higher plasmid copy number and better transformation efficiency). C. glutamicum MB001 was used as host for the production of various value-added compounds: amino acids [96-100], phenylpropanoids [49,52,101], isoprenoids [25,57,102-104], alcohols [105], carboxylic acids $[100,106]$, and proteins [107-110]. In addition, MB001 and derivatives have been used to study Mu-transposition [111], assembly of the septal cell envelope [112], infection with phages $\phi 673$ and $\phi 674$ phages [113], identification of an isoprenoid pyrophosphatedependent transcriptional regulator [114], cAMP phosphodiesterase CpdA [115] and cryptic prophages [94], as basis for ALE towards higher growth rates on glucose minimal medium [116] and to assemble bacterial microcompartments [117].

\section{\#\#.2.2 Prophage-cured lysine producing model strain GRLys1}

The concept of prophage island DNA deletion was transferred from the wild type (see above) to the lysine producing model strain DM1933 [118]. The prophage DNA sequences of the three phages CGP1 CGP and CGP3 were deleted from the base strain DM1933 that contained the following genomic modifications promoting lysine overproduction: $\Delta p c k, p y c^{P 4585}, h^{\text {vom }}{ }^{\text {VIA }}, 2$ copies of lys $C^{T 3111}$, asd, dapA, dapB, ddh, IysA, and lysE [118]. Derivatives of GRLys1 were used to overproduce L-pipecolic acid (L-PA) [27-28,119], 5-aminovaleric acid (5AVA) [34], glutarate [43], and for the coproduction of astaxanthin with lysine [25]. 


\section{\#\#.3 IS element free strain}

\section{\#\#.3.1 MB001 derived IS element free strain CR099}

All copies of IS elements ISCg1 and ISCg2 were deleted from the genome of strain MB001. In addition, it contains mutation A468T in Cg1720 which was inadvertently introduced. Cg1720 encodes the ATPase component of an uncharacterized $A B C$ transporter. This strain was used to characterize synthetases and a hydrolase of the small alarmone (pp)pGpp [120-121]. In a similar approach two IS element-free C. glutamicum strains were derived from ATCC 13032: one lacking IS elements ISCg1a, ISCg1b, ISCg1c, ISCg1e and another lacking ISCg2b, ISCg2c, ISCg2e, ISCg2f [122]. Increased protein production was demonstrated in the IS element free strains [122].

\section{\#\#.4 C. glutamicum chassis strain C1* derived from ATCC 13032}

A chassis strain based on C. glutamicum ATCC 13032 was constructed in a targeted top-down approach. As target function uncompromised growth in glucose minimal medium was chosen. C. glutamicum MB001 was used as starting strain. Next, genes were classified as known to be non-essential from prior experiments, likely non-essential based on transposon mutagenesis screens, unclassifiable or likely essential due to high conservation (Fig. \#\#.1). From these, genomic clusters with genes classified as (likely) non-essential were chosen for deletion from the genome of MB001. The generated deletion mutants were evaluated with respect to growth in glucose minimal medium. This phenotyping step proved crucial to identify nonessential gene clusters that are irrelevant for maintaining the biological fitness of the wild type (WT). A total of 26 gene clusters were found to be non-essential and their individual deletions shown not to compromise growth in glucose minimal medium. 
Based on this mutant collection, combinatorial deletions of these gene clusters was performed resulting in a library of 28 strains. After statistical analysis of a thorough phenotypic screen and one genetic correction, the final chassis strain $\mathrm{C} 1$ * exhibiting a genome reduction of $13.4 \%$ (412 deleted genes; Fig. \#\#.2), but showing wild-type-like growth behavior in glucose minimal medium, robustness against several stresses (including oxygen limitation) and long-term growth stability in defined and complex growth media, was selected [123].

Notably, genome sequencing of the penultimate strain, named $\mathrm{C} 1$, revealed a mutation in the promoter-region of regulatory gene $\operatorname{ramA}[124]$, i.e. a promoter-down mutation (TGCACT instead of the conserved -10-region TACACT). Moreover, this mutation is located in the SugR binding sites overlapping the -10 region [125-126]. A transcriptome analysis revealed 6 fold reduced $\operatorname{ramA}$ RNA levels and reduced RNA levels for several genes of the ramA regulon. Therefore, this point mutation in C. glutamicum C1 was reversed to yield the chassis strain $C$. glutamicum $\mathrm{C} 1 *[123]$.

C. glutamicum C1* $^{*}$ showed slightly impaired growth with some alternative carbon sources such as acetate, pyruvate, arabitol and gluconate. These results are possible since the target function chosen was uncompromised growth with glucose as sole carbon and energy source. However, these physiological peculiarities have to be remembered when constructing and evaluating $\mathrm{C}^{*}$ derived strains for production purposes. As in the case of reversion of the ramA promoter down mutation present in $\mathrm{C} 1$, other SNPs may have to be reverted to allow for fast growth with acetate, pyruvate, gluconate or arabitol.

For all glucose-based production purposes, C. glutamicum $\mathrm{C} 1^{*}$ is an ideal starting point for metabolic engineering as a biotechnologically relevant chassis.

\section{\#\#.5 Applications of genome reduced strains}


\#\#.5.1 Applications of prophage-cured strain MB001 and derivatives

C. glutamicum MB001 found manifold biotechnological applications (Table \#\#.1). Derivatives of this prophage-cured strain were used for the production of proteins [107], citrulline [9697], proline [98], lysine [99], decaprenoxanthin [102-103], astaxanthin [25,57], ciprofloxacintriggered glutamate and oxoglutarate production [100], valencene [104], 3-hydroxypropionic acid [106], coproduction of 1,3-propanediol and glutamate [105], and phenylpropanoids $[49,52,101]$

As an example, the construction and use of strain MB001(DE3) for protein production based on an IPTG-inducible T7 expression system will be discussed. Part of the DE3 region from the protein production host $E$. coli $\mathrm{BL} 21$ (DE3) including the T7 RNA polymerase gene 1 driven by the E. coli lacUV5 promoter, which also is active in C. glutamicum, was integrated into the chromosome of C. glutamicum MB001 [107]. The corresponding expression vector pMKEx2 was developed to express a) the lacl gene encoding $E$. coli lac repressor and b) genes of interest under the control of a T7 promoter followed by lacO1 for induction by IPTG [107]. The inducibility of the system was shown to be 450 fold when expression of the fluorescence protein reporter gene eyfp was analyzed. Fully IPTG-induced T7 RNA polymerase-dependent expression was about 3.5 times higher than expression from the fully IPTG-induced tac promoter in a control strain with the endogenous RNA polymerase. Importantly, fully IPTGinduced T7 RNA polymerase-dependent expression led to a uniform population with $99 \%$ of all cells showing high fluorescence as shown by flow cytometry [107]. As an impressive application example, overexpression of the endogenous pyruvate kinase gene pyk was demonstrated. The already very high pyk gene expression in the wild type (leading to a specific pyruvate kinase activity of $2.6 \mathrm{U} / \mathrm{mg}$ ) was boosted about 50 fold (135 U/mg) [107]. 


\section{\#\#.5.2 CORYNEX}

Besides, C. glutamicum strain ATCC13869 was commercialized as a protein expression system under the trademark CORYNEX ${ }^{\circledR}$ by the Japanese company Ajinomoto. When using the CORYNEX $^{\circledR}$ strain YDK010, secretion of the Fab fragment of human anti-HER2 was low. Deletion of the genes encoding penicillin-binding protein (PBP1a), which is involved in cell wall peptidoglycan synthesis, and the surface (S)-layer protein CspB, showed a synergistic effect allowing efficient Fab production using the CORYNEX ${ }^{\circledR}$ system. This indicated at least two major permeability barriers to Fab secretion, i.e. peptidoglycan and the S-layer [127].

\section{\#\#.5.3 Applications of prophage-cured strain GRLys1 and derivatives}

Derivatives of GRLys1 were used to overproduce 5AVA [34], L-PA [27-28,119], glutarate [43], and for the coproduction of astaxanthin with lysine [25].

As example, glutarate production based on the prophage-cured lysine model producer strain GRLys1 will be discussed (Fig. \#\#.1). Systems metabolic engineering included flux enforcement, which refers to coupling a biosynthetic production pathway to a metabolite pathway required for growth. This strategy has previously been applied to amino acid production by $E$. coli and C. glutamicum. Coupling of a production pathway involving a 2oxoglutarate dependent hydroxylase to growth by deletion of 2-oxoglutarate dehydrogenase subunit gene sucA has first been shown for 4-hydroxy-L-isoleucine production by E. coli [128] and later for 4-hydroxy-L-proline production [129]. Thus, these production pathways became part of an artificial TCA cycle. This concept was extended in succinyl-CoA synthetase-negative ( $\triangle$ sucCD), lysine producing $C$. glutamicum strains. In this case, the succinylase branch of Llysine production metabolically complemented the TCA cycle disrupted due to the sucCD deletion [130]. Also coupling of the major ammonium assimilating enzyme glutamate 
dehydrogenase to transamination reactions were used for flux enforcement when cadaverine/putrescine transaminase PutA and GABA/5AVA amino transferase GabT introduced for glutarate production metabolically complemented for the absence of glutamate dehydrogenase [43]. This prophage-cured, flux enforced strain in addition required expression of a heterologous gene for lysine decarboxylase for glutarate production. In this five step synthetic pathway, lysine was decarboxylated to cadaverine by lysine decarboxylase, and cadaverine converted to glutarate by two transamination (catalyzed PutA, GabT) and two oxidation steps (catalyzed by PutD and GabD) to the targeted product glutarate [43].

\section{\#\#.6 Outlook on construction and testing of new genome-reduced strains}

Targets for gene deletions relevant for genome reduction can be scored by CRISPR interference [131] as applied first to C. glutamicum with respect to lysine production [12]. Evaluation of groups of genes for combined deletion can be done by multiplex CRISPRi [132]. Sequential or parallel targeted genome deletions and replacements in C. glutamicum by CRISPR genome editing is facile since this bacterium lacks efficient non-homologous endjoining. Although genome reduction in C. glutamicum has until now relied on genome editing by two-step homologous recombination using the conditionally lethal levansucrase (sacB) for positive selection [133], genome editing by CRISPR/Cas9 or CRISPR/Cpf1 as developed for C. glutamicum [13-15, 134-136] will find application in further genome streamlining.

Highly parallel strain characterization relies on microbioreactor systems that are based either on shaken microtiter plate cultivation devices or on down-scaled stirred tank reactors [137]. These systems allow for optical, non-invasive, online monitoring of important process parameters such as biomass concentration, dissolved oxygen, $\mathrm{pH}$, or reporter protein 
fluorescence. Their use is potentiated by combination with liquid handling robots for automatization of operation procedures. On-line and off-line strain phenotyping under industrially relevant conditions enables identification of the optimal combination of producer strain and bioprocess control strategy. Of course, the strain collections generated in genome reduction projects can be scored very well using microbioreactor systems as has been shown for characterizing growth [138], protein secretion [108-109] or amino acid production $[17,95,118,123,139]$. 
Table \#\#.1 Biotechnological applications using genome-reduced $C$. glutamicum strains

\begin{tabular}{|c|c|c|c|}
\hline Product & Base strain & Production parameter(s) & Reference \\
\hline $\begin{array}{l}\text { 3-hydroxy- } \\
\text { propionic acid }\end{array}$ & & & {$[106]$} \\
\hline arginine & MB001 & $\mathrm{Y}: 0.30 \mathrm{~g} \cdot \mathrm{g}^{-1}$ & [98] \\
\hline astaxanthin & MB001 & $\begin{array}{l}\mathrm{C}: 1.7 \mathrm{mg} \mathrm{g}^{-1} \mathrm{DCW} ; \mathrm{V}: 0.4 \mathrm{mg} \mathrm{L}^{-1} \mathrm{~h}^{-} \\
1 ;\end{array}$ & {$[57,25]$} \\
\hline noreugenin & MB001 & $\mathrm{T}: 53 \mathrm{mg} / \mathrm{L}$ & [140] \\
\hline Citrulline & MB001 & $\begin{array}{l}\mathrm{T}: 44.1 \pm 0.5 \mathrm{mM} ; \mathrm{Y}: 0.38 \pm 0.01 \\
\mathrm{~g} \cdot \mathrm{g}^{-1} ; \mathrm{P}: 0.32 \pm 0.01 \mathrm{~g} \cdot \mathrm{l}^{-1} \cdot \mathrm{h}^{-1}\end{array}$ & [96-97] \\
\hline $\begin{array}{l}\text { coproduction of } \\
\text { 1,3-propanediol } \\
\text { and glutamate }\end{array}$ & & & {$[105]$} \\
\hline $\begin{array}{l}\text { coproduction of } \\
\text { astaxanthin } \\
\text { with glutamate }\end{array}$ & MB001 & $\begin{array}{l}\text { Astaxanthin: } \mathrm{T}: 2.33 \mathrm{mg} \cdot \mathrm{L}^{-1} ; \mathrm{Y}= \\
2.22 \mathrm{~g} \cdot \mathrm{g}^{-1} ; \mathrm{P}: 0.12 \mathrm{mg} \cdot \mathrm{L}^{-1} \cdot \mathrm{h}^{-1} \\
\text { Glutamate: } \mathrm{T}: 0.05 \mathrm{~g} \cdot \mathrm{L}^{-1} ; \mathrm{Y}: 0.13 \\
\mathrm{~g} \cdot \mathrm{g}^{-1} ; \mathrm{V}: 005 \mathrm{~g} \cdot \mathrm{L}^{-1} \cdot \mathrm{h}^{-1}\end{array}$ & {$[25]$} \\
\hline $\begin{array}{l}\text { coproduction of } \\
\text { astaxanthin } \\
\text { with lysine }\end{array}$ & GRLys1 & $\begin{array}{l}\text { Astaxanthin: } \mathrm{T}: 10 \mathrm{mg} \cdot \mathrm{L}^{-1} ; \mathrm{C}: 0.4 \\
\mathrm{mg} \mathrm{g}^{-1} ; \mathrm{Y}=0.07 \mathrm{~g} \cdot \mathrm{g}^{-1} \\
\text { Lysine: } \mathrm{T}: 48 \mathrm{~g} \cdot \mathrm{L}^{-1} ; \mathrm{Y}: 0.35 \mathrm{~g} \cdot \mathrm{g}^{-1}\end{array}$ & {$[25]$} \\
\hline $\begin{array}{l}\text { coproduction of } \\
\text { decaprenoxanth } \\
\text { in with } \\
\text { glutamate }\end{array}$ & MB001 & $\begin{array}{l}\text { Decaprenoxanthin: } \mathrm{T}: 8.66 \\
\mathrm{mg} \cdot \mathrm{L}^{-1} ; \mathrm{Y}=0.97 \mathrm{~g} \cdot \mathrm{g}^{-1} ; \mathrm{P}: 0.05 \\
\mathrm{mg} \cdot \mathrm{L}^{-1} \cdot \mathrm{h}^{-1} \\
\text { Glutamate: } \mathrm{T}: 0.02 \mathrm{~g} \cdot \mathrm{L}^{-1} ; \mathrm{Y}: 0.48 \\
\mathrm{~g} \cdot \mathrm{g}^{-1} ; \mathrm{V}: 0.18 \mathrm{~g} \cdot \mathrm{L}^{-1} \cdot \mathrm{h}^{-1}\end{array}$ & {$[25]$} \\
\hline $\begin{array}{l}\text { coproduction of } \\
\text { decaprenoxanth } \\
\text { in with lysine }\end{array}$ & GRLys1 & $\begin{array}{l}\text { Decaprenoxanthin: } \mathrm{T}: 6.10 \\
\mathrm{mg} \cdot \mathrm{L}^{-1} ; \mathrm{Y}=0.34 \mathrm{~g} \cdot \mathrm{g}^{-1} ; \mathrm{P}: 0.19 \\
\mathrm{mg} \cdot \mathrm{L}^{-1} \cdot \mathrm{h}^{-1} \\
\text { Lysine: } \mathrm{T}: 2.79 \mathrm{~g} \cdot \mathrm{L}^{-1} ; \mathrm{Y}: 0.15 \mathrm{~g} \cdot \mathrm{g}^{-1} \\
\mathrm{~V}: 0.09 \mathrm{~g} \cdot \mathrm{L}^{-1} \cdot \mathrm{h}^{-1}\end{array}$ & {$[25]$} \\
\hline $\begin{array}{l}\text { Decaprenoxanth } \\
\text { in }\end{array}$ & MB001 & C: $0.4 \mathrm{mg} \mathrm{g}^{-1} \mathrm{DCW}$ & [102-103] \\
\hline $\begin{array}{l}\text { Glutamate } \\
\text { (triggered by } \\
\text { ciprofloxycin) }\end{array}$ & MB001 & $\mathrm{T}: 37 \mathrm{mM} ; \mathrm{Y}: 0.13 \mathrm{~g} \mathrm{~g}^{-1}$ & {$[100]$} \\
\hline lycopene & MB001 & $C: 0.43 \mathrm{mg} \mathrm{g}^{-1} \mathrm{DCW}$ & {$[57,25]$} \\
\hline lysine & & & [99] \\
\hline ornithine & MB001 & $\mathrm{Y}: 0.52 \mathrm{~g} \cdot \mathrm{g}^{-1}$ & [98] \\
\hline $\begin{array}{l}\text { Oxoglutarate } \\
\text { (triggered by } \\
\text { ciprofloxycin) }\end{array}$ & MB001 & $\mathrm{T}: 18 \mathrm{mM}$ & {$[100]$} \\
\hline $\begin{array}{l}\text { 4-hydroxy- } \\
\text { butyrate }\end{array}$ & MB001 & $\mathrm{T}: 3.3 \mathrm{~g} \mathrm{~g}^{-1}$ & [49] \\
\hline
\end{tabular}




\begin{tabular}{|l|l|l|l|}
\hline resveratrol & MB001 & T: $158 \mathrm{mg} \mathrm{L}^{-1}$ & {$[101,52]$} \\
\hline Proline & MB001 & Y: $0.29 \mathrm{~g} \cdot \mathrm{g}^{-1}$ & {$[98]$} \\
\hline Proteins & MB001 & Pyruvate kinase: sp.act. 135 U/mg & {$[107]$} \\
\hline $\begin{array}{l}\text { Protocatechuat } \\
\text { e }\end{array}$ & MB001 & $\mathrm{T}: 2 \mathrm{~g} \mathrm{~g}^{-1}$ & {$[49]$} \\
\hline Putrescine & MB001 & $\mathrm{Y}: 0.17 \mathrm{~g} \cdot \mathrm{g}^{-1}$ & {$[98]$} \\
\hline zeaxanthin & MB001 & $\mathrm{C}: 1.2 \mathrm{mg} \mathrm{g}^{-1} \mathrm{DCW}$ & {$[102-103]$} \\
\hline$\beta$-carotene & MB001 & $\mathrm{C}: 12 \mathrm{mg} \mathrm{g}^{-1} \mathrm{DCW} ; \mathrm{V}: 3.4 \mathrm{mg} \mathrm{L}^{-1} \mathrm{~h}^{-1}$ & {$[57,25]$} \\
\hline
\end{tabular}

Abbreviations: T: titer or concentration in culture broth, $\mathrm{Y}$ : product yield on substrate (unless

otherwise indicated glucose was used as substrate); V: volumetric productivity; C: cellular content; CDW: cell dry weight. 
A

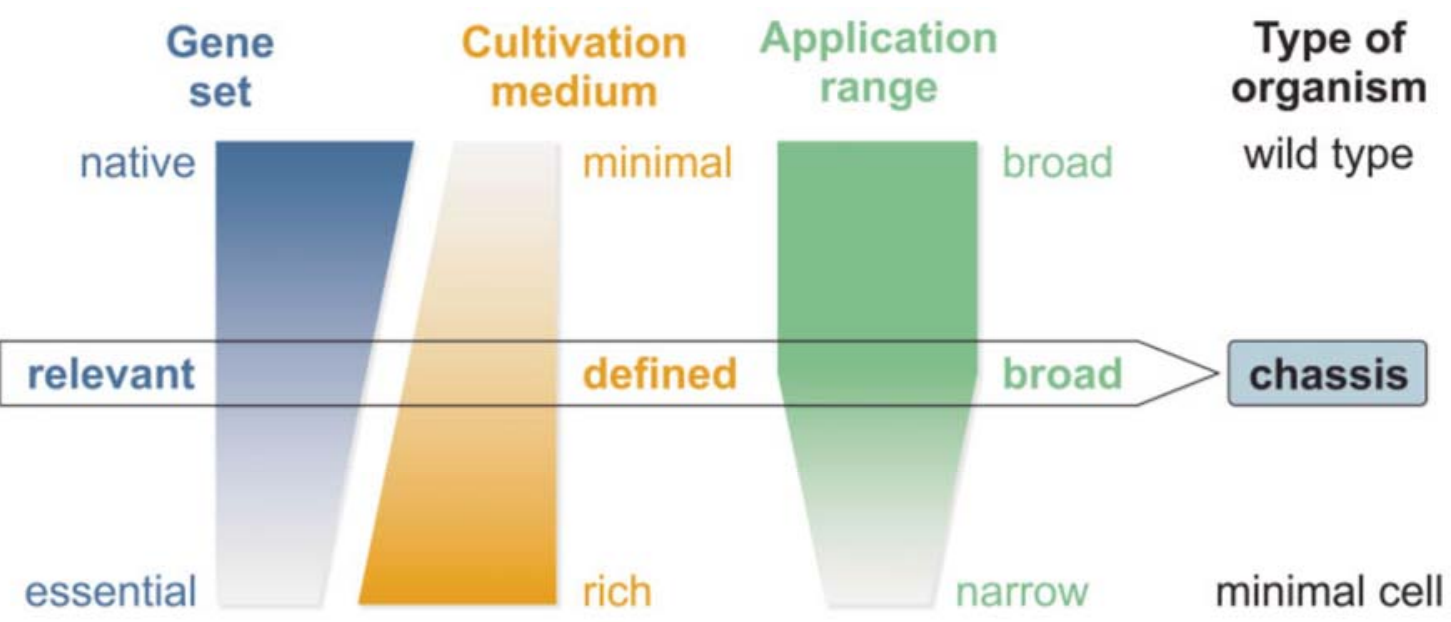

B

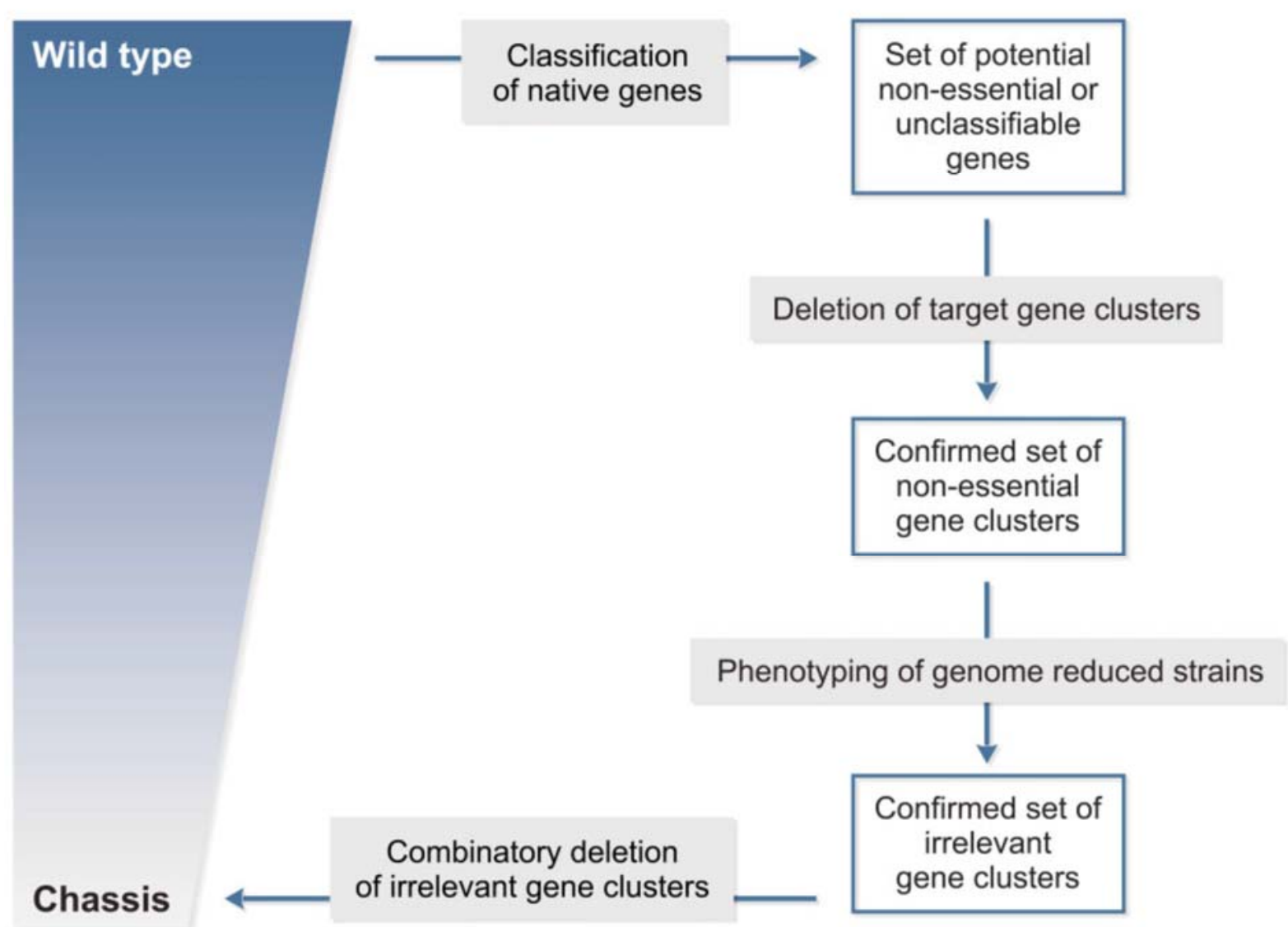

Fig. \#\#.1. Definitions and workflow for the construction of a chassis organism of Corynebacterium glutamicum (Copyright (c) 2015 Unthan, Baumgart, Radek, Herbst, Siebert, Brühl, Bartsch, Bott, Wiechert, Marin, Hans, Krämer, Seibold, Frunzke, Kalinowski, Rückert, Wendisch, Noack; reproduced from [118]). (A) Definitions considering the interplay of gene set, cultivation medium, and application range for different types of organisms. (B) Scheme of our targeted top-down approach toward a chassis covering only genes that are relevant for 
growth on defined medium and maintaining the broad application range of the wild-type organism. 


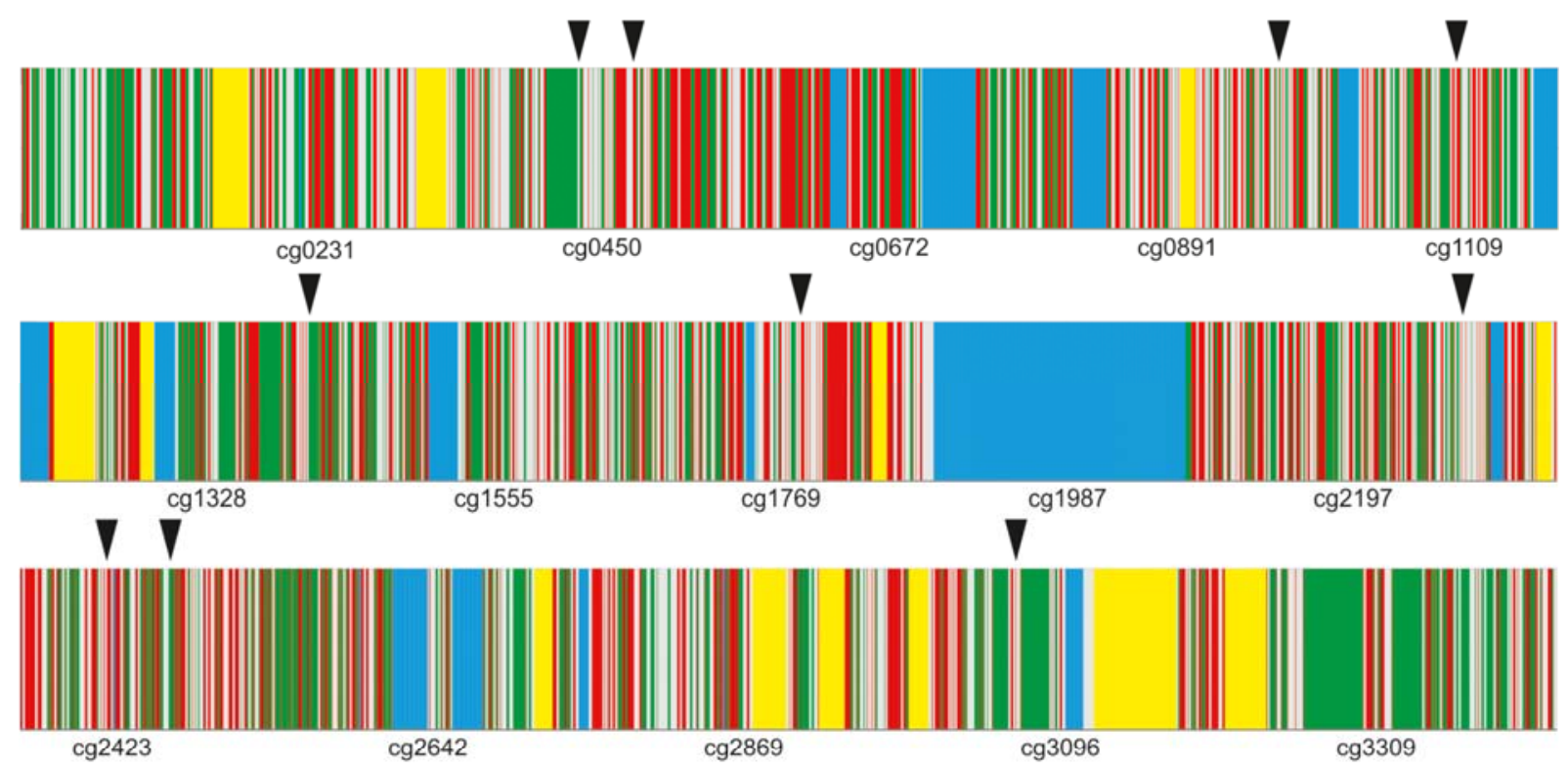

Gene number

\section{Gene classification}

Essential Non-essential $\square$ Unclassifiable Deleted in $\mathrm{C} 1^{*}$

Not deletable or negative effect on growth in defined CGXII medium

Fig. \#\#.2. C. glutamicum ATCC 13032 genome map with classification results of essential, nonessential and unclassifiable genes. (Copyright (C) Reprinted with permission from Baumgart M, Unthan S, Kloss R, Radek A, Polen T, Tenhaef N, Muller MF, Kuberl A, Siebert D, Bruhl N, Marin K, Hans S, Kramer R, Bott M, Kalinowski J, Wiechert W, Seibold G, Frunzke J, Ruckert C, Wendisch VF, Noack S (2018) Corynebacterium glutamicum Chassis C1*: Building and Testing a Novel Platform Host for Synthetic Biology and Industrial Biotechnology. ACS Synth Biol 7 (1):132-144. Copyright 2018 American Chemical Society. [123]). All clusters deleted in $\mathrm{C}^{*}$ are shown in blue. Clusters that could not be deleted or deletions leading to impaired growth in defined CGXII medium are shown in yellow. Black arrows are pointing toward glycolysis genes pgi (cg0973), pfkA (cg1409), fda (cg3068), tpi (cg1789), gap (cg1791), pgk (cg1790), gpmA (cg0482), eno (cg1111), pyk (cg2291), aceE (cg2466), Ipd (cg0441), and $\operatorname{sucB}(\operatorname{cg} 2421)$. 


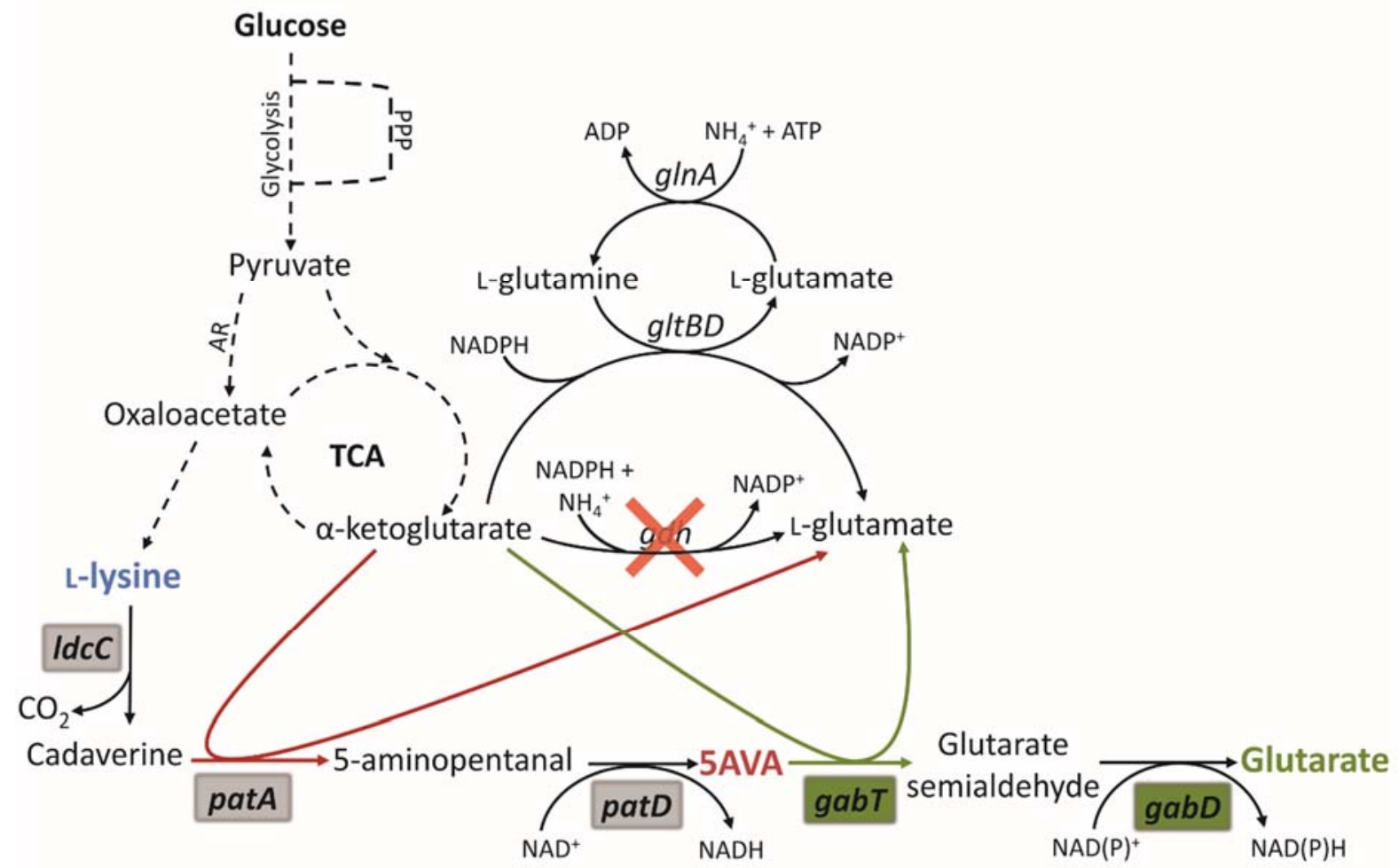

Fig. \#\#.3 Schematic representation of the metabolic engineering strategy for glutarate production by recombinant C. glutamicum (Copyright (C) 2018 Pérez-García, Jorge, Dreyszas, Risse and Wendisch; reproduced from [43]). The biosynthetic pathway for glutarate production was implemented by heterologous expression in a L-lysine producer and coupled with endogenous L-glutamate synthesis. PPP, pentose phosphate pathway; TCA, tricarboxylic acid cycle; AR, anaplerotic reactions; glnA, glutamine synthase gene; glt $B D$, glutamine aminotransferase complex genes; gdh, glutamate dehydrogenase; IdcC, L-lysine decarboxylase; patA, putrescine transaminase; patD, $\gamma$-aminobutyraldehyde dehydrogenase; gabT, GABA/5AVA amino transferase gene; gabD, succinate/glutarate-semialdehyde dehydrogenase gene. Magenta arrows depict transamination reaction in the 5AVA pathway. Green arrows depict transamination reaction in the glutarate pathway. Gray shadowed genes 
are originally from E. coli and were added by heterologous overexpression. Green shadowed genes are originally from C. glutamicum, P. putida, P. syringae, or P. stutzeri and were added by heterologous overexpression. 
References

1. Frazzetto G (2003) White biotechnology. EMBO Rep 4 (9):835-837. doi: 10.1038/sj.embor.embor928

2. Lee JH, Wendisch VF (2017) Production of amino acids - Genetic and metabolic engineering approaches. Bioresour Technol 245 (Pt B):1575-1587. doi: 10.1016/j.biortech.2017.05.065

3. Wendisch VF (2019) Metabolic engineering advances and prospects for amino acid production. Metab Eng. doi: 10.1016/j.ymben.2019.03.008

4. Leuchtenberger W, Huthmacher K, Drauz K (2005) Biotechnological production of amino acids and derivatives: current status and prospects. Appl Microbiol Biotechnol 69 (1):1-8

5. Ohnishi J, Mizoguchi H, Takeno S, Ikeda M (2008) Characterization of mutations induced by $N$-methyl- $N$ '-nitro- $N$-nitrosoguanidine in an industrial Corynebacterium glutamicum strain. Mutat Res 649 (1-2):239-244

6. Kirchner O, Tauch A (2003) Tools for genetic engineering in the amino acid-producing bacterium Corynebacterium glutamicum. J Biotechnol 104 (1-3):287-299

7. Ikeda M (2003) Amino acid production processes. Adv Biochem Eng Biotechnol 79:1-35

8. Ma Q, Zhang Q, Xu Q, Zhang C, Li Y, Fan X, Xie X, Chen N (2017) Systems metabolic engineering strategies for the production of amino acids. Synth Syst Biotechnol 2 (2):8796. doi: 10.1016/j.synbio.2017.07.003

9. Wendisch VF (2014) Microbial production of amino acids and derived chemicals: Synthetic biology approaches to strain development. Curr Opin Biotechnol 30C:51-58. doi: 10.1016/j.copbio.2014.05.004

10. Becker J, Wittmann C (2012) Bio-based production of chemicals, materials and fuels Corynebacterium glutamicum as versatile cell factory. Curr Opin Biotechnol 23 (4):631640. doi: 10.1016/j.copbio.2011.11.012

11. Contador CA, Rizk ML, Asenjo JA, Liao JC (2009) Ensemble modeling for strain development of L-lysine-producing Escherichia coli. Metab Eng 11 (4-5):221-233. doi: 10.1016/j.ymben.2009.04.002

12. Cleto S, Jensen JV, Wendisch VF, Lu TK (2016) Corynebacterium glutamicum Metabolic Engineering with CRISPR Interference (CRISPRi). ACS Synth Biol 5 (5):375-385. doi: 10.1021/acssynbio.5b00216

13. Cho JS, Choi KR, Prabowo CPS, Shin JH, Yang D, Jang J, Lee SY (2017) CRISPR/Cas9coupled recombineering for metabolic engineering of Corynebacterium glutamicum. Metab Eng 42:157-167. doi: 10.1016/j.ymben.2017.06.010

14. Jiang Y, Qian F, Yang J, Liu Y, Dong F, Xu C, Sun B, Chen B, Xu X, Li Y, Wang R, Yang S (2017) CRISPR-Cpf1 assisted genome editing of Corynebacterium glutamicum. Nat Commun 8:15179. doi: 10.1038/ncomms15179

15. Wang Y, Liu Y, Liu J, Guo Y, Fan L, Ni X, Zheng X, Wang M, Zheng P, Sun J, Ma Y (2018) MACBETH: Multiplex automated Corynebacterium glutamicum base editing method. Metab Eng 47:200-210. doi: 10.1016/j.ymben.2018.02.016

16. Zhao FL, Zhang C, Tang Y, Ye BC (2016) A genetically encoded biosensor for in vitro and in vivo detection of NADP. Biosens Bioelectron 77:901-906. doi: 10.1016/j.bios.2015.10.063

17. Steffen V, Otten J, Engelmann S, Radek A, Limberg M, Koenig BW, Noack S, Wiechert W, Pohl M (2016) A Toolbox of Genetically Encoded FRET-Based Biosensors for Rapid LLysine Analysis. Sensors (Basel) 16 (10). doi: 10.3390/s16101604 
18. Mahr R, Gätgens C, Gätgens J, Polen T, Kalinowski J, Frunzke J (2015) Biosensor-driven adaptive laboratory evolution of L-valine production in Corynebacterium glutamicum. Metab Eng 32:184-194. doi: 10.1016/j.ymben.2015.09.017

19. Eggeling L, Bott M, Marienhagen J (2015) Novel screening methods--biosensors. Curr Opin Biotechnol 35:30-36. doi: 10.1016/j.copbio.2014.12.021

20. Siedler S, Schendzielorz G, Binder S, Eggeling L, Bringer S, Bott M (2014) SoxR as a singlecell biosensor for NADPH-consuming enzymes in Escherichia coli. ACS Synth Biol 3 (1):41-47. doi: 10.1021/sb400110j

21. Mustafi N, Grünberger A, Mahr R, Helfrich S, Noh K, Blombach B, Kohlheyer D, Frunzke J (2014) Application of a genetically encoded biosensor for live cell imaging of L-valine production in pyruvate dehydrogenase complex-deficient Corynebacterium glutamicum strains. PLoS One 9 (1):e85731. doi: 10.1371/journal.pone.0085731

22. Mustafi N, Grünberger A, Kohlheyer D, Bott M, Frunzke J (2012) The development and application of a single-cell biosensor for the detection of L-methionine and branchedchain amino acids. Metab Eng 14 (4):449-457. doi: 10.1016/j.ymben.2012.02.002

23. Zhou LB, Zeng AP (2015) Exploring lysine riboswitch for metabolic flux control and improvement of L-lysine synthesis in Corynebacterium glutamicum. ACS Synth Biol 4 (6):729-734. doi: 10.1021/sb500332c

24. Zhou LB, Zeng AP (2015) Engineering a Lysine-ON Riboswitch for Metabolic Control of Lysine Production in Corynebacterium glutamicum. ACS Synth Biol 4 (12):1335-1340. doi: 10.1021/acssynbio.5b00075

25. Henke NA, Wiebe D, Perez-Garcia F, Peters-Wendisch P, Wendisch VF (2018)

Coproduction of cell-bound and secreted value-added compounds: Simultaneous production of carotenoids and amino acids by Corynebacterium glutamicum. Bioresour Technol 247:744-752. doi: 10.1016/j.biortech.2017.09.167

26. Sgobba E, Stumpf AK, Vortmann M, Jagmann N, Krehenbrink M, Dirks-Hofmeister ME, Moerschbacher B, Philipp B, Wendisch VF (2018) Synthetic Escherichia coli-

Corynebacterium glutamicum consortia for L-lysine production from starch and sucrose. Bioresour Technol 260:302-310. doi: 10.1016/j.biortech.2018.03.113

27. Perez-Garcia F, Max Risse J, Friehs K, Wendisch VF (2017) Fermentative production of Lpipecolic acid from glucose and alternative carbon sources. Biotechnol J 12 (7). doi: 10.1002/biot.201600646

28. Perez-Garcia F, Peters-Wendisch P, Wendisch VF (2016) Engineering Corynebacterium glutamicum for fast production of L-lysine and L-pipecolic acid. Appl Microbiol Biotechnol 100 (18):8075-8090. doi: 10.1007/s00253-016-7682-6

29. Mindt M, Heuser M, Wendisch VF (2019) Xylose as preferred substrate for sarcosine production by recombinant Corynebacterium glutamicum. Bioresour Technol 281:135142. doi: 10.1016/j.biortech.2019.02.084

30. Mindt M, Risse JM, Gruss H, Sewald N, Eikmanns BJ, Wendisch VF (2018) One-step process for production of $\mathrm{N}$-methylated amino acids from sugars and methylamine using recombinant Corynebacterium glutamicum as biocatalyst. Sci Rep 8 (1):12895. doi: 10.1038/s41598-018-31309-5

31. Mindt M, Walter T, Risse JM, Wendisch VF (2018) Fermentative Production of NMethylglutamate From Glycerol by Recombinant Pseudomonas putida. Front Bioeng Biotechnol 6:159. doi: 10.3389/fbioe.2018.00159

32. Jorge JM, Leggewie C, Wendisch VF (2016) A new metabolic route for the production of gamma-aminobutyric acid by Corynebacterium glutamicum from glucose. Amino Acids. doi: 10.1007/s00726-016-2272-6 
33. Jorge JM, Nguyen AQ, Perez-Garcia F, Kind S, Wendisch VF (2017) Improved fermentative production of gamma-aminobutyric acid via the putrescine route: Systems metabolic engineering for production from glucose, amino sugars, and xylose. Biotechnol Bioeng 114 (4):862-873. doi: 10.1002/bit.26211

34. Jorge JMP, Perez-Garcia F, Wendisch VF (2017) A new metabolic route for the fermentative production of 5-aminovalerate from glucose and alternative carbon sources. Bioresour Technol 245 (Pt B):1701-1709. doi: 10.1016/j.biortech.2017.04.108

35. Rohles CM, Giesselmann G, Kohlstedt M, Wittmann C, Becker J (2016) Systems metabolic engineering of Corynebacterium glutamicum for the production of the carbon-5 platform chemicals 5-aminovalerate and glutarate. Microb Cell Fact 15 (1):154. doi: 10.1186/s12934-016-0553-0

36. Imao K, Konishi R, Kishida M, Hirata Y, Segawa S, Adachi N, Matsuura R, Tsuge Y, Matsumoto T, Tanaka T, Kondo A (2017) 1,5-Diaminopentane production from xylooligosaccharides using metabolically engineered Corynebacterium glutamicum displaying beta-xylosidase on the cell surface. Bioresour Technol 245 (Pt B):1684-1691. doi: 10.1016/j.biortech.2017.05.135

37. Schneider J, Wendisch VF (2011) Biotechnological production of polyamines by bacteria: recent achievements and future perspectives. Appl Microbiol Biotechnol 91 (1):17-30. doi: 10.1007/s00253-011-3252-0

38. Wieschalka S, Blombach B, Bott M, Eikmanns BJ (2013) Bio-based production of organic acids with Corynebacterium glutamicum. Microb Biotechnol 6 (2):87-102. doi: 10.1111/1751-7915.12013

39. Tsuge $Y$, Tateno T, Sasaki K, Hasunuma T, Tanaka T, Kondo A (2013) Direct production of organic acids from starch by cell surface-engineered Corynebacterium glutamicum in anaerobic conditions. AMB Express 3 (1):72. doi: 10.1186/2191-0855-3-72

40. Kim EM, Um Y, Bott M, Woo HM (2015) Engineering of Corynebacterium glutamicum for growth and succinate production from levoglucosan, a pyrolytic sugar substrate. FEMS Microbiol Lett 362 (19). doi: 10.1093/femsle/fnv161

41. Litsanov B, Brocker M, Bott M (2012) Toward homosuccinate fermentation: metabolic engineering of Corynebacterium glutamicum for anaerobic production of succinate from glucose and formate. Appl Environ Microbiol 78 (9):3325-3337. doi: 10.1128/AEM.07790-11

42. Litsanov B, Brocker M, Bott M (2013) Glycerol as a substrate for aerobic succinate production in minimal medium with Corynebacterium glutamicum. Microb Biotechnol 6 (2):189-195. doi: 10.1111/j.1751-7915.2012.00347.x

43. Perez-Garcia F, Jorge JMP, Dreyszas A, Risse JM, Wendisch VF (2018) Efficient Production of the Dicarboxylic Acid Glutarate by Corynebacterium glutamicum via a Novel Synthetic Pathway. Front Microbiol 9:2589. doi: 10.3389/fmicb.2018.02589

44. Otten A, Brocker M, Bott M (2015) Metabolic engineering of Corynebacterium glutamicum for the production of itaconate. Metab Eng 30:156-165. doi: 10.1016/j.ymben.2015.06.003

45. Blombach B, Riester T, Wieschalka S, Ziert C, Youn JW, Wendisch VF, Eikmanns BJ (2011) Corynebacterium glutamicum tailored for efficient isobutanol production. Appl Environ Microbiol 77 (10):3300-3310. doi: 10.1128/AEM.02972-10

46. Smith KM, Cho KM, Liao JC (2010) Engineering Corynebacterium glutamicum for isobutanol production. Appl Microbiol Biotechnol 87 (3):1045-1055. doi: 10.1007/s00253-010-2522-6 
47. Siebert D, Wendisch VF (2015) Metabolic pathway engineering for production of 1,2propanediol and 1-propanol by Corynebacterium glutamicum. Biotechnol Biofuels 8:91. doi: 10.1186/s13068-015-0269-0

48. Syukur Purwanto H, Kang MS, Ferrer L, Han SS, Lee JY, Kim HS, Lee JH (2018) Rational engineering of the shikimate and related pathways in Corynebacterium glutamicum for 4-hydroxybenzoate production. J Biotechnol 282:92-100. doi: 10.1016/j.jbiotec.2018.07.016

49. Kallscheuer N, Marienhagen J (2018) Corynebacterium glutamicum as platform for the production of hydroxybenzoic acids. Microb Cell Fact 17 (1):70. doi: 10.1186/s12934018-0923-x

50. Kitade Y, Hashimoto R, Suda M, Hiraga K, Inui M (2018) Production of 4-Hydroxybenzoic Acid by an Aerobic Growth-Arrested Bioprocess Using Metabolically Engineered Corynebacterium glutamicum. Appl Environ Microbiol 84 (6). doi: 10.1128/AEM.0258717

51. Veldmann KH, Minges H, Sewald N, Lee JH, Wendisch VF (2019) Metabolic engineering of Corynebacterium glutamicum for the fermentative production of halogenated tryptophan. J Biotechnol 291:7-16. doi: 10.1016/j.jbiotec.2018.12.008

52. Kallscheuer N, Vogt M, Stenzel A, Gatgens J, Bott M, Marienhagen J (2016) Construction of a Corynebacterium glutamicum platform strain for the production of stilbenes and (2S)-flavanones. Metab Eng 38:47-55. doi: 10.1016/j.ymben.2016.06.003

53. Zha J, Zang Y, Mattozzi M, Plassmeier J, Gupta M, Wu X, Clarkson S, Koffas MAG (2018) Metabolic engineering of Corynebacterium glutamicum for anthocyanin production. Microb Cell Fact 17 (1):143. doi: 10.1186/s12934-018-0990-z

54. Chassagnole C, Letisse F, Diano A, Lindley ND (2002) Carbon flux analysis in a pantothenate overproducing Corynebacterium glutamicum strain. Mol Biol Rep 29 (12):129-134

55. Taniguchi H, Wendisch VF (2015) Exploring the role of sigma factor gene expression on production by Corynebacterium glutamicum: sigma factor $\mathrm{H}$ and $\mathrm{FMN}$ as example. Front Microbiol 6:740. doi: 10.3389/fmicb.2015.00740

56. Henke NA, Wichmann J, Baier T, Frohwitter J, Lauersen KJ, Risse JM, Peters-Wendisch P, Kruse O, Wendisch VF (2018) Patchoulol Production with Metabolically Engineered Corynebacterium glutamicum. Genes (Basel) 9 (4). doi: 10.3390/genes9040219

57. Henke NA, Heider SA, Peters-Wendisch P, Wendisch VF (2016) Production of the Marine Carotenoid Astaxanthin by Metabolically Engineered Corynebacterium glutamicum. Mar Drugs 14 (7). doi: 10.3390/md14070124

58. Jo SJ, Matsumoto K, Leong CR, Ooi T, Taguchi S (2007) Improvement of poly(3hydroxybutyrate) $[\mathrm{P}(3 \mathrm{HB})]$ production in Corynebacterium glutamicum by codon optimization, point mutation and gene dosage of $\mathrm{P}(3 \mathrm{HB})$ biosynthetic genes. J Biosci Bioeng 104 (6):457-463

59. Hoffmann J, Altenbuchner J (2014) Hyaluronic acid production with Corynebacterium glutamicum: effect of media composition on yield and molecular weight. J Appl Microbiol 117 (3):663-678. doi: 10.1111/jam.12553

60. Cheng F, Luozhong S, Yu H, Guo Z (2019) Biosynthesis of chondroitin in engineered Corynebacterium glutamicum. J Microbiol Biotechnol. doi: 10.4014/jmb.1810.10062

61. Freudl R (2017) Beyond amino acids: Use of the Corynebacterium glutamicum cell factory for the secretion of heterologous proteins. Journal of Biotechnology 258:101-109. doi: 10.1016/j.jbiotec.2017.02.023 
62. Freudl R (2018) Signal peptides for recombinant protein secretion in bacterial expression systems. Microbial Cell Factories 17. doi: 10.1186/s12934-018-0901-3

63. Zahoor A, Lindner SN, Wendisch VF (2012) Metabolic engineering of Corynebacterium glutamicum aimed at alternative carbon sources and new products. Comput Struct Biotechnol J 3:e201210004. doi: 10.5936/csbj.201210004

64. Wendisch VF, Brito LF, Gil Lopez M, Hennig G, Pfeifenschneider J, Sgobba E, Veldmann KH (2016) The flexible feedstock concept in Industrial Biotechnology: Metabolic engineering of Escherichia coli, Corynebacterium glutamicum, Pseudomonas, Bacillus and yeast strains for access to alternative carbon sources. J Biotechnol 234:139-157. doi: 10.1016/j.jbiotec.2016.07.022

65. Kalinowski J, Bathe B, Bartels D, Bischoff N, Bott M, Burkovski A, Dusch N, Eggeling L, Eikmanns BJ, Gaigalat L, Goesmann A, Hartmann M, Huthmacher K, Kramer R, Linke B, McHardy AC, Meyer F, Mockel B, Pfefferle W, Puhler A, Rey DA, Ruckert C, Rupp O, Sahm H, Wendisch VF, Wiegrabe I, Tauch A (2003) The complete Corynebacterium glutamicum ATCC 13032 genome sequence and its impact on the production of Laspartate-derived amino acids and vitamins. J Biotechnol 104 (1-3):5-25

66. Ikeda M, Nakagawa S (2003) The Corynebacterium glutamicum genome: features and impacts on biotechnological processes. Appl Microbiol Biotechnol 62 (2-3):99-109

67. Wendisch VF (2003) Genome-wide expression analysis in Corynebacterium glutamicum using DNA microarrays. J Biotechnol 104 (1-3):273-285

68. Wendisch VF, Bott M, Kalinowski J, Oldiges M, Wiechert W (2006) Emerging Corynebacterium glutamicum systems biology. J Biotechnol 124 (1):74-92. doi: 10.1016/j.jbiotec.2005.12.002

69. Feist AM, Henry CS, Reed JL, Krummenacker M, Joyce AR, Karp PD, Broadbelt $L$, Hatzimanikatis V, Palsson BO (2007) A genome-scale metabolic reconstruction for Escherichia coli K-12 MG1655 that accounts for 1260 ORFs and thermodynamic information. Mol Syst Biol 3:121. doi: 10.1038/msb4100155

70. Shinfuku Y, Sorpitiporn N, Sono M, Furusawa C, Hirasawa T, Shimizu H (2009) Development and experimental verification of a genome-scale metabolic model for Corynebacterium glutamicum. Microb Cell Fact 8:43. doi: 10.1186/1475-2859-8-43

71. Kjeldsen KR, Nielsen J (2009) In silico genome-scale reconstruction and validation of the Corynebacterium glutamicum metabolic network. Biotechnol Bioeng 102 (2):583-597. doi: 10.1002/bit.22067

72. Zhang Y, Shang X, Wang B, Hu Q, Liu S, Wen T (2019) Reconstruction of tricarboxylic acid cycle in Corynebacterium glutamicum with a genome-scale metabolic network model for trans-4-hydroxyproline production. Biotechnol Bioeng 116 (1):99-109. doi: 10.1002/bit.26818

73. Pauling J, Rottger R, Tauch A, Azevedo V, Baumbach J (2012) CoryneRegNet 6.0--Updated database content, new analysis methods and novel features focusing on community demands. Nucleic Acids Res 40 (Database issue):D610-614. doi: 10.1093/nar/gkr883

74. Pfeifer-Sancar K, Mentz A, Ruckert C, Kalinowski J (2013) Comprehensive analysis of the Corynebacterium glutamicum transcriptome using an improved RNAseq technique. BMC Genomics 14 (1):888. doi: 10.1186/1471-2164-14-888

75. Lee JY, Seo J, Kim ES, Lee HS, Kim P (2013) Adaptive evolution of Corynebacterium glutamicum resistant to oxidative stress and its global gene expression profiling. Biotechnol Lett 35 (5):709-717. doi: 10.1007/s10529-012-1135-9

76. Neshat A, Mentz A, Ruckert C, Kalinowski J (2014) Transcriptome sequencing revealed the transcriptional organization at ribosome-mediated attenuation sites in 
Corynebacterium glutamicum and identified a novel attenuator involved in aromatic amino acid biosynthesis. J Biotechnol 190:55-63. doi: 10.1016/j.jbiotec.2014.05.033

77. Freiherr von Boeselager R, Pfeifer E, Frunzke J (2018) Cytometry meets next-generation sequencing - RNA-Seq of sorted subpopulations reveals regional replication and irontriggered prophage induction in Corynebacterium glutamicum. Sci Rep 8 (1):14856. doi: 10.1038/s41598-018-32997-9

78. Taniguchi $\mathrm{H}$, Henke NA, Heider SAE, Wendisch VF (2017) Overexpression of the primary sigma factor gene sigA improved carotenoid production by Corynebacterium glutamicum: Application to production of $\beta$-carotene and the non-native linear C50 carotenoid bisanhydrobacterioruberin. Metab Eng Comm 4:1-11. doi: 10.1016/j.meteno.2017.01.001

79. Hermann T, Finkemeier M, Pfefferle W, Wersch G, Kramer R, Burkovski A (2000) Twodimensional electrophoretic analysis of Corynebacterium glutamicum membrane fraction and surface proteins. Electrophoresis 21 (3):654-659

80. Schaffer S, Weil B, Nguyen VD, Dongmann G, Gunther K, Nickolaus M, Hermann T, Bott M (2001) A high-resolution reference map for cytoplasmic and membrane-associated proteins of Corynebacterium glutamicum. Electrophoresis 22 (20):4404-4422.

81. Schluesener D, Rogner M, Poetsch A (2007) Evaluation of two proteomics technologies used to screen the membrane proteomes of wild-type Corynebacterium glutamicum and an L-lysine-producing strain. Anal Bioanal Chem 389 (4):1055-1064

82. Fischer F, Poetsch A (2006) Protein cleavage strategies for an improved analysis of the membrane proteome. Proteome Sci 4:2

83. Hansmeier N, Chao TC, Puhler A, Tauch A, Kalinowski J (2006) The cytosolic, cell surface and extracellular proteomes of the biotechnologically important soil bacterium Corynebacterium efficiens YS-314 in comparison to those of Corynebacterium glutamicum ATCC 13032. Proteomics 6 (1):233-250

84. Kuberl A, Polen T, Bott M (2016) The pupylation machinery is involved in iron homeostasis by targeting the iron storage protein ferritin. Proc Natl Acad Sci U S A 113 (17):4806-4811. doi: 10.1073/pnas.1514529113

85. Kuberl A, Franzel B, Eggeling L, Polen T, Wolters DA, Bott M (2014) Pupylated proteins in Corynebacterium glutamicum revealed by MudPIT analysis. Proteomics 14 (12):15311542. doi: 10.1002/pmic.201300531

86. Klatt S, Brammananth R, O'Callaghan S, Kouremenos KA, Tull D, Crellin PK, Coppel RL, McConville MJ (2018) Identification of novel lipid modifications and intermembrane dynamics in Corynebacterium glutamicum using high-resolution mass spectrometry. J Lipid Res 59 (7):1190-1204. doi: 10.1194/jlr.M082784

87. Zhang Q, Zheng X, Wang Y, Yu J, Zhang Z, Dele-Osibanjo T, Zheng P, Sun J, Jia S, Ma Y (2018) Comprehensive optimization of the metabolomic methodology for metabolite profiling of Corynebacterium glutamicum. Appl Microbiol Biotechnol 102 (16):71137121. doi: 10.1007/s00253-018-9095-1

88. Walter F, Grenz S, Ortseifen V, Persicke M, Kalinowski J (2016) Corynebacterium glutamicum ggtB encodes a functional gamma-glutamyl transpeptidase with gammaglutamyl dipeptide synthetic and hydrolytic activity. J Biotechnol 232:99-109. doi: 10.1016/j.jbiotec.2015.10.019

89. Frunzke J, Bramkamp M, Schweitzer JE, Bott M (2008) Population heterogeneity in Corynebacterium glutamicum ATCC 13032 caused by prophage CGP3. J Bacteriol 190 (14):5111-5119 
90. Sindelar G, Wendisch VF (2007) Improving lysine production by Corynebacterium glutamicum through DNA microarray-based identification of novel target genes. Appl Microbiol Biotechnol 76 (3): 677-689. Doi: 10.1007/s00253-007-0916-x

91. Krings E, Krumbach K, Bathe B, Kelle R, Wendisch VF, Sahm H, Eggeling L (2006) Characterization of myo-inositol utilization by Corynebacterium glutamicum: the stimulon, identification of transporters, and influence on L-lysine formation. J Bacteriol 188 (23):8054-8061

92. Nanda AM, Heyer A, Kramer C, Grunberger A, Kohlheyer D, Frunzke J (2014) Analysis of SOS-induced spontaneous prophage induction in Corynebacterium glutamicum at the single-cell level. J Bacteriol 196 (1):180-188. doi: 10.1128/JB.01018-13

93. Helfrich S, Pfeifer E, Kramer C, Sachs CC, Wiechert W, Kohlheyer D, Noh K, Frunzke J (2015) Live cell imaging of SOS and prophage dynamics in isogenic bacterial populations. Mol Microbiol 98 (4):636-650. doi: 10.1111/mmi.13147

94. Pfeifer E, Hunnefeld M, Popa O, Polen T, Kohlheyer D, Baumgart M, Frunzke J (2016) Silencing of cryptic prophages in Corynebacterium glutamicum. Nucleic Acids Res 44 (21):10117-10131. doi: 10.1093/nar/gkw692

95. Baumgart M, Unthan S, Ruckert C, Sivalingam J, Grunberger A, Kalinowski J, Bott M, Noack S, Frunzke J (2013) Construction of a prophage-free variant of Corynebacterium glutamicum ATCC 13032 for use as a platform strain for basic research and industrial biotechnology. Appl Environ Microbiol 79 (19):6006-6015. doi: 10.1128/AEM.01634-13

96. Eberhardt D, Jensen JV, Wendisch VF (2014) L-citrulline production by metabolically engineered Corynebacterium glutamicum from glucose and alternative carbon sources. AMB Express 4:85

97. Lubitz D, Jorge JM, Perez-Garcia F, Taniguchi H, Wendisch VF (2016) Roles of export genes cgmA and lysE for the production of L-arginine and L-citrulline by Corynebacterium glutamicum. Appl Microbiol Biotechnol 100 (19):8465-8474. doi: 10.1007/s00253-016-7695-1

98. Jensen JV, Eberhardt D, Wendisch VF (2015) Modular pathway engineering of Corynebacterium glutamicum for production of the glutamate-derived compounds ornithine, proline, putrescine, citrulline, and arginine. J Biotechnol 214:85-94. doi: 10.1016/j.jbiotec.2015.09.017

99. Wu W, Zhang Y, Liu D, Chen Z (2019) Efficient mining of natural NADH-utilizing dehydrogenases enables systematic cofactor engineering of lysine synthesis pathway of Corynebacterium glutamicum. Metab Eng 52:77-86. doi: 10.1016/j.ymben.2018.11.006

100. Lubitz D, Wendisch VF (2016) Ciprofloxacin triggered glutamate production by Corynebacterium glutamicum. BMC Microbiol 16 (1):235. doi: 10.1186/s12866-0160857-6

101. Kallscheuer N, Vogt M, Kappelmann J, Krumbach K, Noack S, Bott M, Marienhagen J (2016) Identification of the phd gene cluster responsible for phenylpropanoid utilization in Corynebacterium glutamicum. Appl Microbiol Biotechnol 100 (4):1871-1881. doi: 10.1007/s00253-015-7165-1

102. Heider SA, Peters-Wendisch P, Netzer R, Stafnes M, Brautaset T, Wendisch VF (2014) Production and glucosylation of $\mathrm{C} 50$ and $\mathrm{C} 40$ carotenoids by metabolically engineered Corynebacterium glutamicum. Appl Microbiol Biotechnol 98 (3):1223-1235. doi: 10.1007/s00253-013-5359-y

103. Heider SA, Wolf N, Hofemeier A, Peters-Wendisch P, Wendisch VF (2014) Optimization of the IPP Precursor Supply for the Production of Lycopene, Decaprenoxanthin and 
Astaxanthin by Corynebacterium glutamicum. Front Bioeng Biotechnol 2:28. doi: 10.3389/fbioe.2014.00028

104. Binder D, Frohwitter J, Mahr R, Bier C, Grunberger A, Loeschcke A, Peters-Wendisch P, Kohlheyer D, Pietruszka J, Frunzke J, Jaeger KE, Wendisch VF, Drepper T (2016) LightControlled Cell Factories: Employing Photocaged Isopropyl-beta-DThiogalactopyranoside for Light-Mediated Optimization of lac Promoter-Based Gene Expression and (+)-Valencene Biosynthesis in Corynebacterium glutamicum. Appl Environ Microbiol 82 (20):6141-6149. doi: 10.1128/AEM.01457-16

105. Huang J, Wu Y, Wu W, Zhang Y, Liu D, Chen Z (2017) Cofactor recycling for coproduction of 1,3-propanediol and glutamate by metabolically engineered Corynebacterium glutamicum. Sci Rep 7:42246. doi: 10.1038/srep42246

106. Chen Z, Huang J, Wu Y, Wu W, Zhang Y, Liu D (2017) Metabolic engineering of Corynebacterium glutamicum for the production of 3-hydroxypropionic acid from glucose and xylose. Metab Eng 39:151-158. doi: 10.1016/j.ymben.2016.11.009

107. Kortmann M, Kuhl V, Klaffl S, Bott M (2015) A chromosomally encoded T7 RNA polymerase-dependent gene expression system for Corynebacterium glutamicum: construction and comparative evaluation at the single-cell level. Microb Biotechnol 8 (2):253-265. doi: 10.1111/1751-7915.12236

108. Hemmerich J, Moch M, Jurischka S, Wiechert W, Freudl R, Oldiges M (2019) Combinatorial impact of Sec signal peptides from Bacillus subtilis and bioprocess conditions on heterologous cutinase secretion by Corynebacterium glutamicum. Biotechnol Bioeng 116 (3):644-655. doi: 10.1002/bit.26873

109. Hemmerich J, Rohe P, Kleine B, Jurischka S, Wiechert W, Freudl R, Oldiges M (2016) Use of a Sec signal peptide library from Bacillus subtilis for the optimization of cutinase secretion in Corynebacterium glutamicum. Microb Cell Fact 15 (1):208. doi: 10.1186/s12934-016-0604-6

110. Hemmerich J, Tenhaef N, Steffens C, Kappelmann J, Weiske M, Reich SJ, Wiechert W, Oldiges M, Noack S (2018) Less Sacrifice, More Insight: Repeated Low-Volume Sampling of Microbioreactor Cultivations Enables Accelerated Deep Phenotyping of Microbial Strain Libraries. Biotechnol J. doi: 10.1002/biot.201800428

111. Gorshkova NV, Lobanova JS, Tokmakova IL, Smirnov SV, Akhverdyan VZ, Krylov AA, Mashko SV (2018) Mu-driven transposition of recombinant mini-Mu unit DNA in the Corynebacterium glutamicum chromosome. Appl Microbiol Biotechnol 102 (6):28672884. doi: 10.1007/s00253-018-8767-1

112. Zhou X, Rodriguez-Rivera FP, Lim HC, Bell JC, Bernhardt TG, Bertozzi CR, Theriot JA (2019) Sequential assembly of the septal cell envelope prior to $V$ snapping in Corynebacterium glutamicum. Nat Chem Biol 15 (3):221-231. doi: 10.1038/s41589-0180206-1

113. Yomantas YAV, Abalakina EG, Lobanova JS, Mamontov VA, Stoynova NV, Mashko SV (2018) Complete nucleotide sequences and annotations of phi673 and phi674, two newly characterised lytic phages of Corynebacterium glutamicum ATCC 13032. Arch Virol 163 (9):2565-2568. doi: 10.1007/s00705-018-3867-x

114. Henke NA, Heider SAE, Hannibal S, Wendisch VF, Peters-Wendisch P (2017) Isoprenoid Pyrophosphate-Dependent Transcriptional Regulation of Carotenogenesis in Corynebacterium glutamicum. Front Microbiol 8:633. doi: 10.3389/fmicb.2017.00633

115. Schulte J, Baumgart M, Bott M (2017) Identification of the cAMP phosphodiesterase CpdA as novel key player in cAMP-dependent regulation in Corynebacterium glutamicum. Mol Microbiol 103 (3):534-552. doi: 10.1111/mmi.13574 
116. Pfeifer E, Gatgens C, Polen T, Frunzke J (2017) Adaptive laboratory evolution of Corynebacterium glutamicum towards higher growth rates on glucose minimal medium. Sci Rep 7 (1):16780. doi: 10.1038/s41598-017-17014-9

117. Huber I, Palmer DJ, Ludwig KN, Brown IR, Warren MJ, Frunzke J (2017) Construction of Recombinant Pdu Metabolosome Shells for Small Molecule Production in Corynebacterium glutamicum. ACS Synth Biol 6 (11):2145-2156. doi: 10.1021/acssynbio.7b00167

118. Unthan S, Baumgart $M$, Radek A, Herbst $M$, Siebert D, Brühl N, Bartsch A, Bott $M$, Wiechert W, Marin K, Hans S, Krämer R, Seibold G, Frunzke J, Kalinowski J, Rückert C, Wendisch VF, Noack S (2015) Chassis organism from Corynebacterium glutamicum--a top-down approach to identify and delete irrelevant gene clusters. Biotechnol J 10 (2):290-301. doi: 10.1002/biot.201400041

119. Perez-Garcia F, Brito LF, Wendisch VF (2019) Function of L-Pipecolic Acid as Compatible Solute in Corynebacterium glutamicum as Basis for Its Production Under Hyperosmolar Conditions. Front Microbiol 10:340. doi: 10.3389/fmicb.2019.00340

120. Ruwe M, Ruckert C, Kalinowski J, Persicke M (2018) Functional Characterization of a Small Alarmone Hydrolase in Corynebacterium glutamicum. Front Microbiol 9:916. doi: 10.3389/fmicb.2018.00916

121. Ruwe M, Kalinowski J, Persicke M (2017) Identification and Functional Characterization of Small Alarmone Synthetases in Corynebacterium glutamicum. Front Microbiol 8:1601. doi: 10.3389/fmicb.2017.01601

122. Choi JW, Yim SS, Kim MJ, Jeong KJ (2015) Enhanced production of recombinant proteins with Corynebacterium glutamicum by deletion of insertion sequences (IS elements). Microb Cell Fact 14:207. doi: 10.1186/s12934-015-0401-7

123. Baumgart M, Unthan S, Kloss R, Radek A, Polen T, Tenhaef N, Muller MF, Kuberl A, Siebert D, Bruhl N, Marin K, Hans S, Kramer R, Bott M, Kalinowski J, Wiechert W, Seibold G, Frunzke J, Ruckert C, Wendisch VF, Noack S (2018) Corynebacterium glutamicum Chassis C1*: Building and Testing a Novel Platform Host for Synthetic Biology and Industrial Biotechnology. ACS Synth Biol 7 (1):132-144. doi: 10.1021/acssynbio.7b00261

124. Auchter M, Cramer A, Huser A, Ruckert C, Emer D, Schwarz P, Arndt A, Lange C, Kalinowski J, Wendisch VF, Eikmanns BJ (2011) RamA and RamB are global transcriptional regulators in Corynebacterium glutamicum and control genes for enzymes of the central metabolism. J Biotechnol 154 (2-3):126-139. doi: 10.1016/j.jbiotec.2010.07.001

125. Engels V, Lindner SN, Wendisch VF (2008) The global repressor SugR controls expression of genes of glycolysis and of the L-lactate dehydrogenase LdhA in Corynebacterium glutamicum. J Bacteriol 190 (24):8033-8044. doi: 10.1128/JB.00705-08

126. Engels V, Wendisch VF (2007) The DeoR-type regulator SugR represses expression of ptsG in Corynebacterium glutamicum. J Bacteriol 189 (8):2955-2966

127. Matsuda Y, Itaya H, Kitahara Y, Theresia NM, Kutukova EA, Yomantas YA, Date M, Kikuchi Y, Wachi M (2014) Double mutation of cell wall proteins CspB and PBP1a increases secretion of the antibody Fab fragment from Corynebacterium glutamicum. Microb Cell Fact 13 (1):56. doi: 10.1186/1475-2859-13-56

128. Smirnov SV, Kodera T, Samsonova NN, Kotlyarova VA, Rushkevich NY, Kivero AD, Sokolov PM, Hibi M, Ogawa J, Shimizu S (2010) Metabolic engineering of Escherichia coli to produce (2S, 3R, 4S)-4-hydroxyisoleucine. Appl Microbiol Biotechnol 88 (3):719-726. doi: 10.1007/s00253-010-2772-3 
129. Theodosiou E, Breisch M, Julsing MK, Falcioni F, Bühler B, Schmid A (2017) An artificial TCA cycle selects for efficient alpha-ketoglutarate dependent hydroxylase catalysis in engineered Escherichia coli. Biotechnol Bioeng 114 (7):1511-1520. doi: 10.1002/bit.26281

130. Kind S, Becker J, Wittmann C (2013) Increased lysine production by flux coupling of the tricarboxylic acid cycle and the lysine biosynthetic pathway--metabolic engineering of the availability of succinyl-CoA in Corynebacterium glutamicum. Metab Eng 15:184-195. doi: 10.1016/j.ymben.2012.07.005

131. Wiedenheft B, Sternberg SH, Doudna JA (2012) RNA-guided genetic silencing systems in bacteria and archaea. Nature 482 (7385):331-338. doi: 10.1038/nature10886

132. Park J, Shin H, Lee SM, Um Y, Woo HM (2018) RNA-guided single/double gene repressions in Corynebacterium glutamicum using an efficient CRISPR interference and its application to industrial strain. Microb Cell Fact 17 (1):4. doi: 10.1186/s12934-0170843-1

133. Jäger W, Schäfer A, Pühler A, Labes G, Wohlleben W (1992) Expression of the Bacillus subtilis $s a c B$ gene leads to sucrose sensitivity in the gram-positive bacterium Corynebacterium glutamicum but not in Streptomyces lividans. J Bacteriol 174 (16):5462-5465

134. Cameron Coates R, Blaskowski S, Szyjka S, van Rossum HM, Vallandingham J, Patel K, Serber Z, Dean J (2019) Systematic investigation of CRISPR-Cas9 configurations for flexible and efficient genome editing in Corynebacterium glutamicum NRRL-B11474. J Ind Microbiol Biotechnol 46 (2):187-201. doi: 10.1007/s10295-018-2112-7

135. Liu J, Wang Y, Lu Y, Zheng P, Sun J, Ma Y (2017) Development of a CRISPR/Cas9 genome editing toolbox for Corynebacterium glutamicum. Microb Cell Fact 16 (1):205. doi: 10.1186/s12934-017-0815-5

136. Wang B, Hu Q, Zhang Y, Shi R, Chai X, Liu Z, Shang X, Wen T (2018) A RecET-assisted CRISPR-Cas9 genome editing in Corynebacterium glutamicum. Microb Cell Fact 17 (1):63. doi: 10.1186/s12934-018-0910-2

137. Hemmerich J, Noack S, Wiechert W, Oldiges M (2018) Microbioreactor Systems for Accelerated Bioprocess Development. Biotechnol J 13 (4):e1700141. doi: 10.1002/biot.201700141

138. Hemmerich J, Wiechert W, Oldiges M (2017) Automated growth rate determination in high-throughput microbioreactor systems. BMC Res Notes 10 (1):617. doi: 10.1186/s13104-017-2945-6

139. Unthan S, Radek A, Wiechert W, Oldiges M, Noack S (2015) Bioprocess automation on a Mini Pilot Plant enables fast quantitative microbial phenotyping. Microb Cell Fact 14:32. doi: 10.1186/s12934-015-0216-6

140. Milke L, Kallscheuer N, Kappelmann J, Marienhagen J (2019) Tailoring Corynebacterium glutamicum towards increased malonyl-CoA availability for efficient synthesis of the plant pentaketide noreugenin. Microb Cell Fact 18 (1):71. doi: 10.1186/s12934-019$1117-x$ 